\title{
EL USO DE TRATADOS INTERNACIONALES POR PARTE DEL TRIBUNAL CONSTITUCIONAL AL RESOLVER RECURSOS DE INAPLICABILIDAD EN EL PERÍODO 2011-2012*
}

[International Treaties Used by the Constitutional Court When Deciding on Actions of Inapplicability for the 2011-2012 Period]

\author{
Juan Pablo Beca Frei \\ Universidad Católica de Temuco, Chile
}

\begin{abstract}
RESUMEN
El artículo revisa la jurisprudencia sobre el punto de la jerarquía de los tratados internacionales sobre derechos humanos, del impacto del control de convencionalidad y de la interdependencia; con el fin de analizar la jurisprudencia del Tribunal Constitucional, en materia de recursos de inaplicabilidad, en relación al uso de dichos tratados. El Tribunal, sin variar su doctrina, en los hechos los utiliza.
\end{abstract}

Palabras Clave

Tribunal Constitucional - Recurso de inaplicabilidad - Tratados internacionales - Jerarquía - Interdependencia.

\section{Abstract}

This article revises the matters of hierarchy of the international treaties over the human rights, the impact of the conventionality control and the interdependency in the jurisprudence; in order to analyse the Constitutional Court jurisprudence, in matters such as actions of inapplicability, related to the use of said treaties. Without modifying their doctrine, the Court in fact uses them.

\section{KEYWORDS}

Constitutional Court - Actions of inapplicability - International treaties Hierarchy - Interdependency,

ReCiBIDo el 3 de septiembre y ACEPTADo el 15 de diciembre de 2014

* Una versión preliminar y parcial de este trabajo se presentó en las Jornadas de Profesores Jóvenes de Derecho Constitucional, celebradas el año 2013 en la Universidad Católica de Temuco. 


\section{DisCUSIÓN SOBRE LA JERARQUía DE LOS TRATADOS Y LA JURISPRUDENCIA}

Desde hace un cuarto de siglo venimos discutiendo en Chile acerca de la jerarquía de los tratados internacionales sobre derechos humanos, haciéndose indispensable una definición institucional al respecto. Mientras ello no ocurra, el problema debe resolverse por la vía interpretativa ${ }^{1}$. Es la carta fundamental la llamada a definir la jerarquía de los tratados internacionales, incluyendo por cierto aquellos referidos a derechos humanos, pero "la Constitución Política no ha establecido expresamente esta cuestión"2.

La discusión no deja de ser relevante, y cada vez más, toda vez que los tribunales recurren con frecuencia a normativa internacional para resolver los casos que enfrentan. El hecho de que el derecho internacional de los derechos humanos no haya alcanzado un nivel de evolución como el del derecho de la comunidad europea, "no implica que el juez nacional carezca de argumentos para dar aplicación preferente a la normativa internacional"3. Existiendo entonces estos argumentos, habrá que ver si el recurso a la normativa internacional implica que esta se preferirá siempre a la ley interna o solo en algunos y determinados casos.

Nogueira destaca que en Latinoamérica, por regla general, se refuerza "la fuerza normativa de los derechos asegurados por tratados internacionales de derechos humanos" . pero cabe aclarar que ello no ocurre por vía interpretativa, sino que lo han señalado expresamente los correspondientes constituyentes, existiendo por tanto texto expreso al respecto.

La reforma introducida en 1989 al inciso $2^{\circ}$ del artículo 5 CPol. abrió una discusión que, si bien ha avanzado y evolucionado, está lejos de ser zanjada. “Tras la reforma constitucional introducida por la ley N 20.050 (D.O. de 26 de agosto de 2005), el eje de la discusión parece haberse desplazado hacia la posibilidad de controlar - por vía inaplicabilidad- los tratados internaciona-

${ }^{1}$ Henríguez Viñas, Miriam Lorena, Jerarquía de los tratados de derechos humanos: Análisis de casos desde el método jurisprudencial, en Estudios Constitucionales, 6 (2008) 2, p. 113.

${ }^{2}$ NúÑez Poblete, Manuel, La función del derecho internacional de los derechos de la persona en la argumentación de la jurisprudencia constitucional. Práctica y principios metodológicos, en Revista de Derecho de la Pontificia Universidad Católica de Valparaiso, 32 (2009) 1, p. 510.

${ }^{3}$ NúÑez Poblete, Manuel, Introducción al concepto de identidad constitucionaly a su función frente al derecho supranacional e internacional de los derechos de la persona, en Ius et Praxis, 14 (2008) 2, p. 356.

${ }^{4}$ Nogueira Alcalá, Humberto, El uso del derecho convencional internacional de los derechos humanos en la jurisprudencia del Tribunal Constitucional chileno en el periodo 2006-2010, en Revista Chilena de Derecho, 39 (2012) 1, p. 152. 
les o la de utilizar las normas internacionales como parámetro de control de constitucionalidad"s. En este segundo aspecto es en el que nos detendremos en este trabajo, intentando dilucidar cuál ha sido el comportamiento del Tribunal Constitucional en el período 2011-2012.

La postura del Tribunal Constitucional, como demostraremos, no ha contribuido a terminar con la discusión sobre la jerarquía de los tratados internacionales y otorgar certeza a los operadores del sistema jurídico, al contrario, sus resoluciones, en contra de lo que pueda aparecer a primera vista, resultan contradictorias. En la sentencia rol 346, de 8 de abril de 2002, ante un requerimiento presentado por treinta y cinco diputados, el Tribunal Constitucional estableció su doctrina al respecto, revisando ampliamente lo que era hasta ese momento la discusión académica, dedicando a ello los considerandos $59^{\circ}$ a $75^{\circ}$. Para tomar su decisión el Tribunal Constitucional sigue de cerca los planteamientos del profesor Lautaro Ríos Álvarez en el sentido de que los tratados internacionales sobre derechos humanos no tienen rango constitucional ${ }^{6}$. Concluye expresamente el Tribunal Constitucional que "no es posible sostener que un tratado que verse sobre derechos esenciales que emanan de la naturaleza humana enmiende la Constitución en lo que sea contraria a ella o tenga igual jerarquía"7. De allí en adelante se ha afirmado que el aludido Tribunal "se resiste sistemáticamente a reconocer jerarquia constitucional a dichos tratados, a partir de la preeminencia del principio de supremacía de la Constitución".

La postura del Tribunal Constitucional está lejos de ser pacífica. Poco después de conocido el fallo mencionado, Nogueira sostenía: "El fallo de mayoría parece sostener que las normas de derechos humanos contenidos en tratados internacionales estarían comprendidos, desde el punto formal, en el nivel intermedio entre los preceptos legales y la Constitución, con lo que se desnaturaliza el artículo 5 inciso $2^{\circ}$ y la reforma constitucional de 1989 , cuyo objeto y fin fue incorporar con rango constitucional los derechos asegurados por los tratados internacionales, produciéndose una verdadera mutación constitucional por vía interpretativa" ". Las diferencias de opinión

${ }^{5}$ Núñez Poblete, Manuel, La función, cit. (n. 2), p. 490.

${ }^{6}$ Ríos Álvarez, Lautaro, Jerarquía normativa de los tratados internacionales sobre derechos humanos, en Ius et Praxis, 2 (1997) 2, pp. 101-112.

${ }^{7}$ Tribunal Constitucional, Requerimiento de inconstitucionalidad presentado por treinta y cinco Diputados respecto del Estatuto de Roma de la Corte Penal Internacional, adoptado en dicha ciudad el 17 de julio de 1998, rol No346 (2002), p. 98.

${ }^{8}$ NúÑEz Poblete, Manuel, La función, cit. (n. 2), p. 491.

${ }^{9}$ Nogueira Alcalá, Humberto, Los derechos esenciales o humanos contenidos en los tratados internacionales y su ubicación en el ordenamiento juridico nacional: doctrina y jurisprudencia, en Ius et Praxis, 9 (2003) 1, pp. 403-466. 
respecto de la jerarquía de los tratados se pueden apreciar incluso entre los integrantes del Tribunal Constitucional. "Los votos de mayoría y minoría reflejan la evidencia de dos enfoques y concepciones de interpretación constitucional y de concepto de Constitución opuestas"10.

La discrepancia no se da solo en el ámbito doctrinario: "la lectura de la reciente jurisprudencia judicial, especialmente de la constitucional, e incluso de cierta jurisprudencia no jurisdiccional, permite advertir como una tendencia consolidada la notoria apertura de nuestros operadores jurisdiccionales y administrativos hacia dichas fuentes no nacionales de argumentación"11. Analizando la evolución de la jurisprudencia referida a la jerarquía de los tratados internacionales sobre derechos humanos, Henríquez distingue diversas etapas ${ }^{12}$.

La primera de ellas la ubica cronológicamente entre los años 1980-1989, en la que se aplican categorías propias del derecho interno, considerando que "los tratados tenían el mismo valor y jerarquía que la ley"13.

La segunda etapa va desde el año 1989 hasta el año 1994; en esta etapa, tanto en materias vinculadas a la ley de cheques como a deudas previsionales, la Corte de Apelaciones de Santiago sostuvo la preeminencia de un tratado internacional -la Convención americana de derechos humanos- por sobre la legislación chilena, pero este criterio no fue mantenido por la Corte Suprema, considerando, en el primer aspecto, que el tratado era compatible con la legislación interna. En relación a las deudas previsionales, el máximo tribunal consideró que el empleador que no entera las cotizaciones previsionales incurre en un ilícito penal y por ello no se aplica la regla de la Convención que se refiere a deudas civiles. Como se puede observar, en ningún caso la Corte Suprema se pronuncia sobre la jerarquía de los tratados. En casos vinculados a la aplicación de la ley de amnistía, la Corte de Apelaciones de Santiago los resuelve "aplicando preferentemente los tratados por sobre la ley interna, con base en el rango supralegal de los mismos" ${ }^{14}$, pero nuevamente el criterio no es sostenido por la Corte Suprema, evitando, otra vez, resolver el tema de la jerarquía, aduciendo que no se daban algunos supuestos fácticos para la aplicación de convenios internacionales.

La tercera etapa identificada por Henríquez comprende desde los años 1994 a 2005, etapa en la que se discute sobre la jerarquía de los tratados a raíz de casos sobre deudas previsionales y sobre ley de amnistía. En el pri-

\footnotetext{
${ }^{10}$ Nogueira Alcalá, Humberto, Los Derechos, cit. (n. 9).

${ }^{11}$ NúÑez Poblete, Manuel, Introducción, cit. (n. 3), p. 333. La misma idea en Núñez Poblete, Manuel, La función, cit. (n. 3), p. 491.

${ }^{12}$ Henrí $u$ ez Viñas, Miriam Lorena, cit. (n. 1).

${ }^{13}$ Ibíd., p. 81.

${ }^{14}$ Ibíd., p. 92.
} 
mer caso la jurisprudencia fue vacilante en cuanto a considerar si el arresto constituye o no prisión por deuda, pero "cuando la Corte Suprema identificó la incompatibilidad entre el Pacto de San José de Costa Rica y el artículo 12 de la ley 17.322, le atribuyó mayor jerarquía al tratado que a la ley"15. Es interesante notar que, concordando con el criterio de la Corte Suprema, el Tribunal Constitucional, en casos de deuda de cotizaciones previsionales descontadas a los trabajadores, señaló que "no se está en presencia de una prisión por deudas, sino que ante una apropiación indebida del empleador de dineros que son propiedad de los trabajadores" ${ }^{16}$. En relación a la ley de amnistía, a partir de 1996 "la Corte Suprema reconoce igual jerarquía a los tratados que a las leyes, resolviendo el conflicto entre los tratados y la ley de amnistía por el criterio de la temporalidad. Sin embargo, a partir de 1998 reconoce que los tratados de derechos humanos son jerárquicamente superiores a la leyes comunes, pero jerárquicamente inferiores a las leyes de orden público" ${ }^{17}$, considerando que la ley de amnistía tiene este carácter. Se observa que en esta etapa la Corte Suprema sí aborda el tema de la jerarquía, pero introduce una distinción entre leyes ordinarias y de orden público, ubicando a los tratados justamente entre ambas. Este criterio es luego abandonado, aplicando los tratados por sobre las leyes, y por ende dejando de aplicar la mencionada ley de amnistía. "Claramente la decisión de los tribunales en este sentido señala el reconocimiento de una mayor jerarquía de los tratados sobre la legislación interna" 18 .

En la cuarta etapa, que comienza a partir del año 2004, se consolida el criterio recién enunciado, e incluso, al menos en un caso, "con respecto a los tratados internacionales la sentencia [de la Corte de Apelaciones de Santiago] les reconoce fuerza constitucional material" ${ }^{19}$. Además en esta etapa se aprecia que junto a los tratados, la misma jurisprudencia reconoce a las normas de ius cogens "preeminencia sobre las disposiciones internas" ${ }^{20}$. La propia Corte de Apelaciones de Santiago menciona el "control de convencionalidad que impone la Corte Interamericana a los tribunales de justicia chilenos en el caso Almonacid Arellano"21. En esta etapa, concluye Henríquez ${ }^{22}$, se observa como

${ }^{15}$ Ibíd., p. 95.

${ }^{16}$ Nogueira Alcalá, Humberto, Diálogo interjurisdiccional, control de convencionalidad y jurisprudencia del Tribunal Constitucional en periodo 2006-2011, en Estudios Constitucionales, 10 (2012) 2, p. 117.

${ }^{17}$ Henrí́uez ViÑas, Miriam Lorena, cit. (n. 1), p. 96.

${ }^{18}$ Ibíd., p. 100.

${ }^{19}$ Ibíd., p. 107.

${ }^{20}$ Ibíd., p. 107.

${ }^{21}$ Ibíd., p. 111.

${ }^{22}$ Ibíd., p. 113. 
los tribunales superiores prefieren la aplicación de tratados internacionales de derechos humanos por sobre la ley interna, en algunos casos mencionando su rango constitucional y en otros haciendo referencia a su mayor jerarquía respecto de la legislación interna.

Esta tendencia también puede observarse, como demostraremos más adelante, en algunos fallos del Tribunal Constitucional, cuestión que reconoce Núñez al señalar que "después de la reforma de la ley $\mathrm{N}^{\circ} 20.050$ el criterio hermético de nuestro Tribunal Constitucional parece mantenerse aunque comienzan a advertirse gérmenes de cambio, particularmente en el ámbito de la nueva inaplicabilidad"23.

Nogueira señala que en las sentencias roles 740-07 y 1484-09 el Tribunal Constitucional "posibilita a los jueces ordinarios aplicar el 'control de convencionalidad' que exige la Corte Interamericana a los jueces nacionales" ${ }^{\prime 2}$; pero luego advierte que ello no es sinónimo de control de constitucionalidad, cuestión que queda reservada al Tribunal Constitucional y no corresponde por ende al juez de la instancia ${ }^{25}$. De ello se podría colegir que la Constitución y los tratados no comparten una misma jerarquía dentro del ordenamiento jurídico. Sin embargo Núñez avanza más allá al señalar "que el juez tiene el deber de interpretar las normas constitucionales en armonía con las internacionales" ${ }^{26}$, dando la impresión ahora de que sí comparten, a lo menos, la misma jerarquía.

Lo que la Corte Interamericana señala es que los jueces están obligados "a velar porque los efectos de las disposiciones de la Convención no se vean mermadas por la aplicación de leyes contrarias a su objeto y fin" ${ }^{27}$, con lo que parece restringir el control de convencionalidad a las leyes, pero luego, en el mismo considerando, señala: "El Poder Judicial debe ejercer una especie de 'control de convencionalidad' entre las normas jurídicas internas que aplican en los casos concretos y la Convención Americana sobre derechos humanos"28, abriendo ahora este control a toda norma jurídica interna, sin distinguir su naturaleza, y obligando de algún modo a los jueces a transformarse en "jueces interamericanos en el plano nacional" 29 . Para evitar la contradicción entre normas internas, especialmente las constitucionales, con la Convención, una solución podría ser la propuesta por Núñez en el sentido

\footnotetext{
${ }^{23}$ Núñez Poblete, Manuel, La función, cit. (n. 2), p. 497.

${ }^{24}$ Nogueira Alcalá, Humberto, El uso del Derecho cit. (n. 4), p. 154.

${ }^{25}$ Ibíd., p. 154-155.

${ }^{26}$ Núñez Poblete, Manuel, Introducción, cit. (n. 3), p. 358.

${ }^{27}$ Corte Interamericana de derechos humanos, caso "Almonacid Arellano y otros vs. Chile" (2006), p. 77.

${ }^{28}$ Ibíd., p. 77.

${ }^{29}$ Nogueira Alcalá, Humberto, Diálogo cit. (n. 16), p. 60.
} 
de interpretarlas conforme a la normativa internacional. El problema de la jerarquía parece entonces desdibujarse.

\section{INTERDEPENDENCIA Y DIÁLOGO JUDICIAL}

Actualmente el derecho no puede verse como un fenómeno circunscrito a las fronteras del Estado. Observamos cómo se utilizan diversas fuentes de derecho y cómo los jueces dialogan entre ellos, sin importar si pertenecen a una misma jurisdicción o no, e incluso, si provienen o no de una misma tradición jurídica. El control de convencionalidad, exigido por la Corte Interamericana de derechos humanos, es un buen ejemplo de ello. En palabras de Núñez, "el constitucionalismo contemporáneo, al menos en Occidente, se caracteriza por la progresiva interrelación entre las fuentes internas y aquello que puede identificarse con el término 'Derecho no nacional"' 30 . En ese sentido no es de extrañar que el Tribunal Constitucional chileno no se limite a las fuentes internas de Derecho, sino que recurra también a otros instrumentos. Cobra sentido, en esta forma de ver el problema, la referencia -ya clásica- al "catálogo de derechos abierto" ${ }^{31}$ que hace Nogueira.

La posibilidad de perseguir la responsabilidad internacional de los Estados determina "la internacionalización de la Constitución y la constitucionalización del derecho internacional" 32 . En nuestro medio se observa igualmente una tendencia a la internacionalización, y por ello resulta "fácil advertir cómo nuestros órganos legislativos, administrativos y judiciales desarrollan los mandatos constitucionales a partir de premisas cada vez menos nacionalistas y cada vez más internacionalistas" ${ }^{33}$. Fuera del ámbito jurídico se habla de "interdependencia" 34 , queriendo hacer notar que la independencia de los Estados reposa hoy sobre una base de relaciones, cuestión que es perfectamente aplicable al ámbito jurídico y especialmente al tema sobre el que reflexionamos.

Galdámez destaca que el Tribunal Constitucional ha ido incorporando progresivamente no sólo referencias a tratados internacionales, sino también a derecho y jurisprudencia extranjera, tendencia en la que distingue dos etapas: la primera entre los años 2006 y 2007 que denomina "la etapa de las referencia escasas al derecho y jurisprudencia extranjeras" ${ }^{35}$; y la segunda, de-

${ }^{30}$ NúÑEz Poblete, Manuel, La función, cit. (n. 2), p. 488.

${ }^{31}$ Nogueira Alcalá, Humberto, Los derechos, cit. (n. 9).

${ }^{32}$ Nogueira Alcalá, Humberto, El uso del derecho cit. (n. 4), p. 153.

${ }^{33}$ NúÑez Poblete, Manuel, La función, cit. (n. 2), p. 488.

${ }^{34}$ BARBER, Benjamin, Why Interdependence? (Understanding Interdependence Day), s.p.

${ }^{35}$ Galdámez Zelada, Liliana, El uso del derecho y la jurisprudencia extranjera 
nominada "uso creciente de la técnica del derecho comparado" 36 , que la ubica entre los años 2008 y 2010. Sin duda el recursos a fuentes no nacionales viene a complementar la doctrina nacional, por ejemplo, en materia de igualdad ante la ley, en la que se puede observar como en los últimos años el Tribunal Constitucional ha ido llenando de contenido esta garantía constitucional.

\section{USO DE TRATADOS INTERNACIONALES POR PARTE DEL TRIBUNAL CONSTITUCIONAL CHILENo}

El profesor Humberto Nogueira demuestra que con posterioridad a la citada sentencia rol 346 el Tribunal Constitucional sí utiliza tratados internacionales, dándoles un valor a lo menos igual al de la Constitución. Entre los años 2007 y 2010 "hay un uso del derecho internacional de los derechos humanos moderado, con distinta intensidad y objeto por parte del Tribunal Constitucional" 37 , inclusive en casos en que los requirentes no invocan de forma acertada el derecho internacional ${ }^{38}$. En un sentido similar se pronuncia Núñez, quien señala que "en la jurisprudencia de inaplicabilidad es posible advertir una larvada forma de conexión entre la infracción a los convenios internacionales y el artículo 5 CPol" ${ }^{39}$, idea que reitera al señalar que "la propia jurisprudencia del Tribunal Constitucional se está abriendo a la utilización de (por lo menos) fuentes internacionales como parámetros de constitucionalidad" ${ }^{0}$.

En lo que sigue revisaremos sentencias recaídas en recursos de inaplicabilidad en las que, para resolver el asunto, el Tribunal Constitucional recurre a tratados internacionales. Podemos afirmar que siendo la inconstitucionalidad el único supuesto que permite al Tribunal decidir que un determinado precepto es inaplicable, conforme al artículo $93 \mathrm{~N}^{\circ} 6^{\circ}$ de la carta fundamental, declarar un precepto inaplicable por ser contrario a un tratado, implica necesariamente darle a este tratado carácter o rango constitucional, aunque ello no se diga ni se reconozca expresamente.

No consideramos en el presente trabajo los casos en que el Tribunal ha

en los fallos del Tribunal Constitucional de Chile: 2006-2010, en Revista Chilena de Derecho, 39 (2012) 1, p. 192.

${ }^{36}$ Ibíd., p. 193.

${ }^{37}$ Nogueira Alcalá, Humberto, El uso del derecho cit. (n. 4), p. 159.

${ }^{38}$ Ibíd., p. 160.

${ }^{39}$ Núñez Poblete, Manuel, La función, cit. (n. 2), p. 525.

${ }^{40}$ Núñez Poblete, Manuel, Sobre la declaración de inaplicabilidad de los tratados internacionales. Un estudio en defensa de su fundamento y legitimidad, en Estudios Constitucionales, 8 (2010) 2, p. 457. 
evadido (utilizando las categorías de Núñez ${ }^{41}$ sin perjuicio de otras ${ }^{42}$ ) el pronunciamiento, habiendo "sido requerido para declarar la contradicción entre un precepto legal y un instrumento internacional” ${ }^{43}$, por cuanto en esos casos la magistratura constitucional no se ha hecho cargo de los tratados en cuestión.

Agruparemos los casos en las siguientes categorías, utilizando parcialmente las propuestas por Núñez:

a) Los casos ad a bund a ntiam. En estas ocasiones "si se eliminara la referencia al derecho internacional la decisión seguiría siendo la misma”" 44 . Consideramos también como ad abund a n tia m los casos en que se recurre a los tratados internacionales como complemento a la parte dogmática de la Constitución, cuestión que "representa una forma larvada de conexión entre la violación del Derecho internacional de los derechos humanos y el artículo $5 \mathrm{CPol}^{\prime \prime 4}$. A pesar de la insistencia del citado autor en diferenciar esta categoría con la anterior pensamos que es una manifestación de ad abundantiam, por lo que englobaremos ambas categorías en una sola, manteniendo la denominación de la primera de ellas, al analizar los fallos que revisaremos.

b) Los casos en que efectivamente se recurre a los tratados para resolver el asunto, llegando a una solución diversa a la que se pudiere haber arribado si el tratado no exis ti ese. Núñez considera como una categoría las situaciones en que se hace "uso y abuso del Derecho internacional: logrando que los tratados digan lo que no dicen" ${ }^{\prime 4}$. Hemos optado por subsumir esta última categoría en aquella en que efectivamente se recurre al tratado para resolver el asunto, pues determinar si el uso es correcto o abusivo es una cuestión de interpretación, y en este trabajo analizamos el uso de los tratados, no de la interpretación de los mismos.

c) Los casos en que el Tribunal Constitucional explica las razones por las cuales no aplica algún tratado internacion al. En los casos recogidos, la razón por la cual no los utiliza no es un

${ }^{41}$ NúÑEz Poblete, Manuel, La función, cit. (n. 3), pp. 498 ss. distingue las siguientes categorías: la evasión, el recurso retórico ad abundantiam, el complemento de la parte dogmática de la Constitución y el uso y abuso del derecho internacional.

${ }^{42}$ Otras categorías de análisis podrían ser las utilizadas por Nogueira AlCalá, Humberto, Diálogo cit. (n. 16), p. 129, quien distingue la interpretación receptiva, la interpretación correctiva, la interpretación innovadora y la interpretación neutralizadora.

${ }^{43}$ NúÑEz Poblete, Manuel, La función, cit. (n. 2), p. 498.

${ }^{44}$ Ibíd., p. 493.

${ }^{45}$ Ibíd., p. 502.

${ }^{46}$ Ibíd., p. 502. 
problema de jerarquía; al contrario, al argumentar el por qué no los utiliza pareciera ser que les reconoce una naturaleza constitucional. Se verá que los motivos por los cuales el Tribunal no utiliza los tratados internacionales, en los fallos analizados, son cuestiones de hecho, deficiencias en las argumentaciones de las partes y la naturaleza de alguna institución jurídica, pero de ningún modo un rango inferior a la carta constitucional.

1. Casos ad abundantiam.

a) En el fallo roles 1732-10-INA y 1800-10-INA (causas que fueron acumuladas), de 21 de junio de 2012, al referirse a la vida privada, el Tribunal Constitucional sostiene "que el artículo $19, N^{\circ} 4^{\circ}$, de la Constitución, además del derecho al honor y a la honra, asegura a todas las personas el respeto y la protección de la vida privada, el cual debe quedar al amparo de la injerencia de terceras personas. La Constitución procura facilitar asi el pleno ejercicio de la libertad personal sin interferencias ni intromisiones o presiones indebidas. Asi lo establece claramente, por su parte, el artículo $11, N^{\circ} 2$, de la Convención Americana de derechos humanos: "Nadie puede ser objeto de injerencias arbitrarias o abusivas en su vida privada [...]. Toda persona tiene derecho a la protección de la ley contra esas injerencias o esos ataques' [sic]" "47. Es del todo claro que en estos casos la referencia a los Tratados Internacionales no agrega nada nuevo a lo ya establecido por la carta fundamental.

b) En el fallo rol 1803-10-INA, de 12 de mayo de 2011, el Tribunal Constitucional señala "Que el artículo $19, N^{\circ} 17^{\circ}$, constitucional, cuando asegura la admisión a todas las funciones y empleos públicos "sin otros requisitos que los que impongan la Constitución y las leyes" [sic], naturalmente da margen para considerar las condenas penales que puedan presentar los postulantes interesados en ejercer dichos cargos, conforme también permite hacerlo el artículo 23 del Pacto de San José de Costa Rica o Convención Americana sobre derechos bumanos" ${ }^{38}$. Cabe hacer notar que la Convención es más precisa

${ }^{47}$ Tribunal Constitucional, Requerimiento de inaplicabilidad por inconstitucionalidad presentado por Jorge Cabezas Villalobos y otros trabajadores de Televisión Nacional de Chile respecto del artículo décimo, letra h), de la Ley $N^{o} 20.285$, sobre Acceso a la Información Pública, en los autos rol $N^{\circ}$ 945-2010 sobre reclamo de ilegalidad interpuesto ante la Corte de Apelaciones de Santiago en contra del Consejo para la Transparencia; $y$ Requerimiento de inaplicabilidad por inconstitucionalidad presentado por Televisión Nacional de Chile "TVN" respecto de los artículos décimo b) y 33 b) de la Ley $N^{\circ} 20.285$, en los autos rol $N^{\circ}$ 945-2010 sobre reclamo de ilegalidad interpuesto ante la Corte de Apelaciones de Santiago en contra del Consejo para la Transparencia, roles $\mathrm{N}^{\circ} 1732-10-\mathrm{INA}$ y N ${ }^{\circ} 1800-10-I N A$ (acumulados) (2011), p. 25.

${ }^{48}$ Tribunal Constitucional, Requerimiento de inaplicabilidad por inconstitucionalidad presentado por Pedro Santibánez Palma respecto del inciso tercero del artículo 29 de la Ley $N^{\circ} 18.216$, en la causa sobre recurso de protección interpuesto en contra del señor 
que la Constitución chilena, en cuanto limita al legislador, estableciendo taxativamente, en el citado artículo 23 , los casos en que le es lícito establecer requisitos, siendo uno de ellos precisamente la "condena, por juez competente, en proceso penal". En este caso la referencia a la Convención permite al Tribunal sostener que el requisito legal es perfectamente compatible con las exigencias internacionales, pero cabe preguntarse qué habría pasado con un requisito no permitido expresamente por la Convención, toda vez que la Constitución no establece criterios para el legislador, bastando con que sea precisamente la ley, y no la autoridad administrativa, la que establezca los requisitos. En ese sentido, el requisito es perfectamente constitucional, y es, además, compatible por la Convención, pero la omisión a la referencia a la Convención no hubiese cambiado la decisión.

c) En los fallos roles 2035-11-INA ${ }^{49}$ y 2105-11-INA ${ }^{50}$, ambos de 4 de septiembre de 2012, el Tribunal Constitucional reitera su jurisprudencia en el sentido de declarar inaplicable el artículo 206 CC.. Lo hace "por resultar las limitaciones en él contenidas inconciliables con el derecho a la igualdad ante la ley (consagrado en el numeral $2^{\circ}$ del artículo 19 constitucional) y con el derecho a la identidad, proclamado por diversos tratados internacionales suscritos y ratificados por Chile y actualmente vigentes en nuestro país, así como implícito en el concepto de dignidad humana consagrado en el artículo $1^{\circ}$ de la Constitución". Si bien bastaría para declarar inaplicable el referido artículo del Código Civil la incompatibilidad entre este precepto legal y el derecho a la igualdad ante la ley, consagrado en la Constitución, el Tribunal cita, para reforzar su argumento, que el artículo en cuestión es también incompatible con el derecho a la identidad, el que si bien no se consagra en la Constitución, lo deriva el tribunal de diversos tratados internacionales, y en segundo lugar, lo considera implícito en el concepto de dignidad humana consagrado en la Constitución, pero es claro que ello es sólo en segundo lugar, siendo el

Contralor General de la República, que se encuentra pendiente ante la Corte de Apelaciones de Santiago, bajo el rol $N^{\circ} 2602-2010$, rol No 1803-10-INA, p. 10.

${ }^{49}$ Tribunal Constitucional, Requerimiento de inaplicabilidad por inconstitucionalidad presentado por Carolina Rejas López y Juan Rejas López respecto del artículo 206 del Código Civily de los incisos tercero y cuarto, del artículo $5^{\circ}$ transitorio de la ley $N^{\circ} 19.585$, en los autos RIT C-7283-2009, RUC 09-2-0365566, sobre impugnación y reclamación de paternidad no matrimonial sustanciados ante el Cuarto Juzgado de Familia de Santiago, en actual apelación y casación en la forma ante la Corte de Apelaciones de Santiago, bajo el rol $N^{\circ} 1015-2011$, rol N²035-11-INA (2012), p. 4.

${ }^{50}$ Tribunal Constitucional, Requerimiento de inaplicabilidad por inconstitucionalidad presentado por el Juzgado de Familia de Temuco respecto de los artículos 206 del Código Civil y $5^{\circ}$ transitorio de la Ley $N^{\circ} 19.585$, en los autos sobre reclamación de filiación, de que conoce el Juzgado de Familia de Temuco, bajo el RIT C-1975-2011, rol N 2105-11-INA (2012), p. 4. 
principal argumento la referencia a los tratados internacionales. En definitiva, la referencia al derecho a la identidad no cambia la decisión del Tribunal.

d) En el fallo rol 2071-11-INA, de 19 de junio de 2012, el Tribunal falla en base a la existencia del derecho a la honra, el que deriva no sólo del texto constitucional. Considera "que la aplicación delprecepto impugnado también vulnera el derecho a la honra reconocido en el articulo 11 de la Convención Americana sobre derechos humanos" ${ }^{1}$. Al igual que en los casos anteriores, sin referirse a la mencionada Convención, recurriendo únicamente al texto de la Constitución chilena, el Tribunal Constitucional podría haber llegado a la misma conclusión.

2. Casos en que se llega a una solución diversa a la que se hubiese arribado utilizando sólo el texto constitucional.

a) En el fallo rol 1481-09-INA, de 10 de mayo de 2011, conociendo de un recurso de inaplicabilidad respecto del inciso final del artículo 406 CPP., el Tribunal sostiene que "en este sistema, los jueces se ven obligados a integrar las normas de procedimiento con aquellas de carácter constitucional $y$ con los tratados internacionales que son parte integrante de nuestro ordenamiento, por lo que de ser aceptada en esta sede la impugnación del requirente, se estaría desvirtuando prácticamente la columna vertebral del nuevo sistema, partiendo por el rol del juez y del juicio oral [...]. Más aún, lo que está presente en los tratados internacionales incorporados por Chile es un juicio público, transparente y con garantias para las partes" 52 . La referencia a la oralidad del juicio es interesante, pues no se menciona en la Constitución ni en los tratados internacionales, pero se puede derivar de una serie de garantías establecidas en estos últimos, como el derecho a ser oído -y por ende no sólo leído- por un tribunal, el de interrogar y contrainterrogar a los testigos, y otros. El Tribunal Constitucional entiende entonces que el sistema procesal penal resguarda estas garantías, y que por ello no se puede obviar la oralidad ni el rol pasivo del juez, lo que entendemos como una referencia al sistema adversarial en contraposición al inquisitivo. Sin estas garantías establecidas

\footnotetext{
${ }^{51}$ Tribunal Constitucional, Requerimiento de inaplicabilidad por inconstitucionalidad presentado por Daniel Yarur Elsaca respecto del artículo 2331 del Código Civil, en los autos sobre juicio civil por responsabilidad extracontractual e indemnización de perjuicios, caratulados "Yarur con Yarur", de que conoce el Quinto Juzgado Civil de Santiago, bajo el rol $N^{\circ} C$-8.269-2011, rol No 2071-11-INA (2012), p. 15.

${ }^{52}$ Tribunal Constitucional. Requerimiento de inaplicabilidad por inconstitucionalidad presentado por Jesús Manzur Saca respecto del inciso final del artículo 406 del Código Procesal Penal en causa RUC N $0800123624-6$, del Tercer Juzgado de Garantía de Santiago, rol No 1481-09-INA (2011), p. 22.
} 
en los tratados, las características del juicio penal oral serían una cuestión tan sólo legal y no de rango constitucional.

b) En el fallo rol 1683-10-INA, de 4 de enero de 2011, el Tribunal Constitucional se pronuncia sobre el artículo 365 CP., específicamente sobre la eventual discriminación que implica el sancionar penalmente las relaciones homosexuales consentidas con menores de 18 años, en circunstancias que tratándose se relaciones heterosexuales consentidas se sancionan penalmente sólo cuando se realizan con un sujeto menor de 14 años de edad. Para llegar a su decisión el Tribunal analiza en su fallo diversos tratados internacionales, especialmente la Convención de derechos del niño, considerando que se trata de una situación en que están involucrados menores de edad. El Tribunal rechaza el requerimiento, en atención a que "ante todo lo expuesto, forzoso es concluir que el precepto impugnado no contiene una discriminación arbitraria o carente de razonabilidad, ya que se fundamenta en los principios del interés superior del niño y de protección especial, contemplados en instrumentos de derecho internacional que son parte del ordenamiento juridico chileno, en los términos del articulo 5 de la Constitución Politica Chilena, y que obligan a los órganos del Estado -entre ellos, el legislador - a su respeto y promoción" ${ }^{53}$.

Llama la atención, en cuanto al contenido del principio de igualdad, el que si bien éste se encuentra establecido en nuestra Constitución, la carta fundamental no enumera algunas de las circunstancias que el voto disidente de los ministros Hernán Vodanovic Snake, Carlos Carmona Santander y José Antonio Viera-Gallo Quesney denomina “categorías sospechosas" ${ }^{54}$. Siendo la orientación sexual una de estas categorías, al determinar si efectivamente se incurre en una discriminación arbitraria al sancionar relaciones homosexuales consentidas, el Tribunal incorpora al análisis el principio de interés superior del niño, consagrado en la citada Convención sobre los derechos del niño y no en el texto constitucional. Pensamos que respecto del contenido del principio de igualdad los textos internacionales (y la doctrina y jurisprudencia que se han generado en torno a ello) sin duda ayudan a un análisis más rico de nuestro Tribunal Constitucional, pero que se podría haber llegado a la misma construcción de contenido sin recurrir a ellos. Sin embargo, no podemos sostener lo mismo respecto del principio del interés superior del niño, que permite hacer una distinción que de otro modo no estaría autorizada por nuestro ordenamiento jurídico. En definitiva, reconociendo que hay una diferencia, y por ende una discriminación, esta no

\footnotetext{
${ }^{53}$ Tribunal Constitucional. Requerimiento de inaplicabilidad por inconstitucionalidad presentado por Jorge Washington Sepúlveda Álvarez respecto del artículo 365 del Código Penal, en la causa RIT $N^{\circ} 1287-2008$, RUC $N^{\circ} 0800242317-1$, seguida ante el Juzgado de Garantía de Cañete, rol N ${ }^{\circ}$ 1683-10-INA (2011), p. 30.

${ }^{54}$ Ibíd., p. 62.
} 
resulta, a juicio del Tribunal Constitucional, arbitraria -y en consecuencia no resulta inconstitucional- pues la razón para hacer la diferencia se encuentra en un tratado internacional, cual es la Convención sobre los derechos del niño.

c) En el fallo rol 1718-10-INA, de 14 de junio de 2011, el Tribunal Constitucional, respecto del principio de presunción de inocencia, sostiene: "En tratados internacionales sobre derechos humanos ratificados por Chile si aparece reconocido formalmente. La Convención americana sobre derechos humanos -"Pacto de San José de Costa Rica"-, en el artículo 8.2, dispone que 'toda persona inculpada de delito tiene derecho a que se presuma su inocencia mientras no se establezca legalmente su culpabilidad' [sic] y que 'durante el proceso toda persona tiene derecho, en plena igualdad, a las garantías mínimas' que enuncia. A su vez, el Pacto internacional de derechos civiles y políticos, en el artículo 14.2, reitera que 'toda persona acusada de un delito tiene derecho a que se presuma su inocencia mientras no se pruebe su culpabilidad conforme a la ley"'55. El texto constitucional prohíbe presumir de derecho la responsabilidad penal, pero no establece abierta y directamente la obligación de presumir inocente a quien es acusado de un delito. Resulta evidente que en este caso el Tribunal Constitucional recurre a tratados internacionales para afirmar la existencia de este principio. Si bien el principio se encuentra recogido en el artículo 4 CPP., es claro que el Tribunal Constitucional no puede fallar en base a una disposición legal, por lo que recurre entonces a los tratados internacionales citados para sostener que en Chile sí existe el principio de presunción de inocencia.

d) En los fallos roles 1804-2010-INA, de 29 de marzo de $2012^{56}$ y 1888-10-INA, de 3 de abril del mismo año ${ }^{57}$, los recursos de inaplicabilidad resultaron rechazados al producirse un empate de votos entre los ministros del Tribunal Constitucional. Entre los argumentos de quienes estuvieron por acoger los respectivos recursos, se sostuvo que "uno de los elementos fun-

${ }^{55}$ Tribunal Constitucional, Requerimiento de inaplicabilidad por inconstitucionalidad presentado por Adolfo Hernán Fuenzalida Cerpa respecto del artículo 163, letra e), inciso primero, del Código Tributario, en los autos rol $N^{\circ}$ 55-2010 sobre recurso de apelación en materia criminal interpuesto ante la Corte de Apelaciones de Valdivia en contra de la sentencia pronunciada por el Segundo Juzgado de Letras de Osorno en causa rol $N^{o}$ 5295-2009 sobre delitos tributarios, rol No 1718-10-INA (2011), p. 16.

${ }^{56}$ Tribunal Constitucional, Requerimiento de inaplicabilidad por inconstitucionalidad presentado por José Ignacio Lara Ostornol respecto del inciso final del articulo 40 de la Ley $N^{\circ} 18.287$, en los autos rol $N^{\circ} 366-2010$, sobre recurso de hecho interpuesto ante la Corte de Apelaciones de Valparaiso, rol No 1804-2010-INA (2012), pp. 9-10.

${ }^{57}$ Tribunal Constitucional, Requerimiento de inaplicabilidad por inconstitucionalidad presentado por Daniel Adrián Costagliola Mellado respecto del artículo 40 de la Ley $N^{o} 18.287$, en los autos rol $N^{\circ} 3973-2010$, sobre recurso de hecho interpuesto ante la Corte de Apelaciones de Santiago, rol No 1888-10-INA (2012), pp. 12-13. 
damentales propios de un justo y racional procedimiento es la circunstancia de que exista la posibilidad de que las partes puedan impugnar lo resuelto ante un tribunal superior jerárquico. Si bien es cierto, como también lo ha sentenciado esta magistratura, la Constitución Política de la República no establece propiamente el derecho a una apelación, sise ha entendido como constitutiva de un debido proceso la existencia de una vía de impugnación adecuada. Ello también se ha reconocido en diversos tratados internacionales, especialmente en procesos penales, como es el caso del Pacto internacional de derechos civiles y políticos (artículo 14.5, que alude al derecho a un tribunal superior), la Convención americana de derechos humanos (articulo 8.2.h, que consagra el derecho de recurrir del fallo ante juez o tribunal superior) o el Tratado europeo de derechos humanos (articulo 13). De esta forma, si bien el articulo $19 \mathrm{~N}^{\circ} 3^{\circ}$, inciso sexto, de la Carta Fundamental no indica una a una cuáles son las formalidades esenciales de un proceso, cuestión por lo demás ajena a una Carta Fundamental, ello no implica que el legislador pueda mutilar la garantía de que se trata en punto a poder eliminar arbitrariamente el recurso a un tribunal superior".

A su vez, quienes estuvieron por rechazar los recursos, argumentaron también en base a tratados internacionales, aunque sin mencionar expresamente algunos de ellos, aduciendo que al regular el debido proceso, el Congreso Nacional "debe respetar los derechos esenciales que emanan de la naturaleza humana, los derechos reconocidos en tratados internacionales de derechos humanos y vigentes en Chile y, especialmente, el contenido esencial de los derechos" se señaló en uno ${ }^{58}$ y otro caso ${ }^{59}$. Cabe hacer notar que al revisar detenidamente los tratados se llega, en este caso particular, a una comprensión más cabal de lo que es el debido proceso, y en particular, de la exigencia, derivada de ellos, de establecer algún modo de impugnación de los fallos de los tribunales ordinarios.

e) En el fallo rol 1852-10-INA, de 26 de julio de 2011, el Tribunal Constitucional, luego de analizar disposiciones de la Declaración universal de derechos humanos y del Pacto internacional de derechos económicos, sociales y culturales, concluye que "la garantía constitucional de libertad de trabajo y su protección que declara el artículo $19 N^{\circ} 16^{\circ}$ de la Constitución Politica de la República, incluye el reconocimiento de que todo operario debe gozar de condiciones de trabajo equitativas y satisfactorias, lo que implica que pueda disponer de descanso adecuado y exista una limitación razonable de la duración del

${ }^{58}$ Tribunal Constitucional, Requerimiento de inaplicabilidad por inconstitucionalidad presentado por José Ignacio Lara Ostornol, cit. (n. 56), p. 31.

${ }^{59}$ Tribunal Constitucional, Requerimiento de inaplicabilidad por inconstitucionalidad presentado por Daniel Adrián Costagliola Mellado, cit. (n. 57), p. 37. 
tiempo de trabajo, que le permita disfrutar de tiempo libre para compatibilizar sus obligaciones laborales con los otros aspectos de su vida"60.

La Constitución chilena, en el artículo $19 \mathrm{~N}^{\circ} 16$, no se refiere a las horas de descanso ni a las vacaciones, cuestiones que, en el medio nacional, se encuentran tratadas en el Código del Trabajo, pero que a nivel internacional sí se encuentran contempladas en los tratados que consideró el Tribunal Constitucional $^{61}$. Así, al igual que en el caso anterior, si bien el Tribunal no puede recurrir a normas legales para fundar su decisión, sí lo hace recurriendo a tratados internacionales.

f) En el caso del fallo rol 1968-2011-INA, de 15 de mayo de 2012, el Tribunal Constitucional concluye que los órganos del Estado deben respetar el principio non bis in ídem por mandato de tratados internacionales, aun cuando no se encuentre expresamente consagrado en la Constitución. Dice el fallo: "Así resulta pertinente recordar que el Pacto Internacional de Derechos Civiles y Políticos, de 1966, promulgado por Decreto Supremo $\mathrm{N}^{\circ}$ 778, del Ministerio de Relaciones Exteriores, de 1989, indica, en su artículo $14 \mathrm{~N}^{\circ}$ 7, que: "Nadie podrá ser juzgado ni sancionado por un delito por el cual y a haya sido condenado o absuelto por una sentencia firme de acuerdo con la ley y el procedimiento penal de cada pais." [sic] La Convención Americana de derechos humanos, de 1969, promulgada por Decreto Supremo $\mathrm{N}^{\circ} 873$, del Ministerio de Relaciones Exteriores, de 1991, establece, a su vez, en su artículo $8 \mathrm{~N}^{\circ} 4$, que: "El inculpado absuelto por una sentencia firme no podrá ser sometido a nuevo juicio por los mismos hechos"62.

Se advierte, una vez más, como el Tribunal Constitucional debe recurrir a tratados internacionales para afirmar la existencia de una garantía que, como expresamente reconoce, no se encuentra consagrada en la Constitución.

g) En los fallos roles 1960-11-INA ${ }^{63}$ y 1961-11-INA, de 10 de julio de

${ }^{60}$ Tribunal Constitucional, Requerimiento de inaplicabilidad por inconstitucionalidad presentado por el Segundo Juzgado de Letras de Talagante respecto del artículo 26 bis del Código del Trabajo, en los autos laborales RIT 103-10-T.L. sobre denuncia de tutela de derechos fundamentales y cobro de prestaciones e indemnizaciones, sustanciados ante el Segundo Juzgado de Letras de Talagante, rol N 1852-10-INA (2011), pp. 17-18.

${ }^{61}$ Aun cuando se podría discutir el carácter de tratado de la Declaración Universal de derechos humanos, el Tribunal Constitucional le dio tal carácter al resolver el caso en análisis.

${ }^{62}$ Tribunal Constitucional, Requerimiento de inaplicabilidad por inconstitucionalidad deducido por Sociedad Starco S.A. respecto del numeral primero, letra a), del artículo único de la Ley $N^{\circ} 20.238$, que agrega una oración final en el inciso primero del artículo $4^{\circ}$ de la Ley $N^{\circ} 19.886$, en los autos rol $N^{\circ} 416-2011$ sobre recurso de protección interpuesto ante la Corte de Apelaciones de Santiago en contra de la Dirección de Compras y Contratación Pública y de la Dirección del Trabajo, rol No 1968-2011-INA (2012), pp. 32-33.

${ }^{63}$ Tribunal Constitucional, Requerimiento de inaplicabilidad por inconstitucionali- 
2012 $2^{64}$, y roles 2018-11-INA ${ }^{65}$ y 2108-11-INA, de 7 de agosto del mismo año, se produce también un empate, y al igual que en el caso anterior, en los considerandos de las dos votos se invocan tratados internacionales.

Los votos por acoger los recursos discurren sobre lo que denomina el principio de inocencia, mientras que los votos por rechazarlos lo hacen sobre el principio non bis in íd e m. En el primer caso, el argumento señala que "el precepto objetado aparece transgrediendo el mandato constitucional que prohibe al legislador presumir de derecho la responsabilidad penal. De éste -en armonia con el derecho a la libertad individual y la seguridad de que los preceptos limitativos de las garantías no pueden afectar la esencia de las mismas- se deduce indirectamente el principio de inocencia, claramente consignado en tratados internacionales suscritos por Chile, como la Convención americana sobre derechos humanos y el Pacto internacional de derechos civiles y políticos".

Respecto de las referencias al principio "non bis in idem", se cita el fallo 1968-2011-INA ${ }^{66}$, para sostener que "respecto a la consagración del principio de 'non bis in ídem', sin perjuicio de que no tenga un reconocimiento constitucional explícito, debe deducirsele -en su fazprocesal-del debidoproceso, consagrado en el artículo $19 \mathrm{~N}^{\circ} 3^{\circ}$, como también "ha de entenderse que forma parte del conjunto de derechos que los órganos del Estado deben respetar y promover en virtud del mandato contenido en el inciso segundo del artículo $5^{\circ}$ de la Constitución, el que reconoce como fuente de esos derechos tanto a la propia Carta Fundamental como a los tratados internacionales ratificadospor Chiley que se encuentran vigentes" (STC rol $\mathrm{N}^{\circ} 1968$, considerando $41^{\circ}$ ), especialmente en relación al artículo $14 \mathrm{~N}^{\circ} 7 \mathrm{del}$ Pacto internacional de derechos civiles y politicos y al artículo $8 \mathrm{~N}^{\circ} 4$ de la Convención americana de derechos humanos" ${ }^{\prime 67}$.

dad presentado por el Juez de Policía Local de María Pinto respecto de los artículos 207, letra b), de la Ley $N^{o} 18.290$ y 39 y 40 de la Ley $N^{\circ} 18.287$, en los autos rol $N^{\circ} 348-2011$, sobre acumulación de infracciones a la Ley de Tránsito seguidos ante el Juzgado de Policía Local de María Pinto, rol No 1960-11-INA (2012), p. 7.

${ }^{64}$ Tribunal Constitucional, Requerimiento de inaplicabilidad por inconstitucionalidad presentado por el Juez de Policía Local de María Pinto respecto de los artículos 207, letra b), de la Ley $N^{\circ} 18.290$ y 39 y 40 de la Ley $N^{\circ} 18.287$, en los autos rol $N^{\circ} 348-2011$, sobre acumulación de infracciones a la Ley de Tránsito seguidos ante el Juzgado de Policía Local de María Pinto en contra de Leonardo Tomás Montecinos García, rol No 1961-11INA (2012).p. 7.

${ }^{65}$ Tribunal Constitucional, Requerimiento de inaplicabilidad por inconstitucionalidad presentado por el Juzgado de Policía Local de Maria Pinto respecto de los artículos 207 , letra b), de la Ley $N^{\circ} 18.290$ y 39 y 40 de la Ley $N^{\circ} 18.287$, en los autos rol $N^{\circ} 553-$ 2011 sobre acumulación de infracciones a la Ley de Tránsito seguidos ante el Juzgado de Policía Local de María Pinto en contra de Carlos Jorge Velásquez Vargas, rol N ${ }^{\circ} 2018$ 11-INA (2012), p. 23.

${ }^{66}$ Fallo que ya se analizó en el presente trabajo.

${ }^{67}$ Tribunal Constitucional, Requerimiento de inaplicabilidad por inconstitucio- 
En los fallos roles 1960-11-INA ${ }^{68}$ y 1961-11-INA ${ }^{69}$, ya mencionados, se agrega además, estableciendo una relación entre la prohibición de establecer penas excesivas y el mencionado principio n on bis in íde m, que "hade entenderse que forma parte del conjunto de derechos que los órganos del Estado deben respetar y promover en virtud de lo que dispone el articulo $19 \mathrm{~N}^{\circ} 1^{\circ}$, inciso final, en relación con los artículos 7 del Pacto internacional de derechos civiles y políticos y $5^{\circ} N^{\circ} 1$ inciso $2^{\circ}$, de la Convención americana de derechos humanos y 16 de la Convención contra la tortura”.

$\mathrm{Al}$ igual como ocurre cuando el Tribunal resuelve sobre la exigencia de establecer mecanismos de impugnación de las decisiones judiciales, ahora, al referirse a la presunción de inocencia, en una opinión, y al principio n o n $\mathrm{b}$ is in íd e m, en la otra, lo hace argumentando en base a tratados internacionales, pues la normativa constitucional, por sí sola, no le permite resolver, de la forma como lo hace, el asunto sometido a su decisión.

b) En el fallo rol 2045-11-INA, de 7 de junio de 2012, el Tribunal Constitucional sostiene, basándose en tratados internacionales, que la prohibición de presumir de derecho la responsabilidad penal implica reconocer el principio de presunción de inocencia. Señala textualmente: "Que, también, el precepto objetado aparece transgrediendo el mandato constitucional queprobibe al legislador presumir de derecho la responsabilidad penal. De éste - en armonía con el derecho a la libertad individual y la seguridad de que los preceptos limitativos de las garantias no pueden afectar la esencia de las mismas-se deduce indirectamente el principio de inocencia, claramente consignado en tratados internacionales suscritos por Chile, como la Convención americana sobre derechos humanos y el Pacto internacional de derechos civiles y políticos"70. Lo

nalidad presentado por el Juez de Policía Local de María Pinto cit. (n. 63), pp. 18-19; Tribunal Constitucional, Requerimiento de inaplicabilidad por inconstitucionalidad presentado por el Juez de Policía Local de María Pinto cit, (n. 65), pp. 19-20; Tribunal Constitucional, Requerimiento de inaplicabilidad por inconstitucionalidad presentado por el Juez de Policia Local de María Pinto cit, (n. 66), p. 10; Tribunal Constitucional, Requerimiento de inaplicabilidad por inconstitucionalidad presentado por el Juez de Policia Local de María Pinto, cit. (n. 65), pp. 10-11.

${ }^{68}$ Tribunal Constitucional, Requerimiento de inaplicabilidad por inconstitucionalidad presentado por el Juez de Policía Local de María Pinto, cit. (n. 63), pp. 18-19.

${ }^{69}$ Tribunal Constitucional, Requerimiento de inaplicabilidad por inconstitucionalidad presentado por el Juez de Policía Local de María Pinto, cit. (n. 64), p. 19.

${ }^{70}$ Tribunal Constitucional, Requerimiento de inaplicabilidad por inconstitucionalidad deducido por Evelyn Benavides Simon respecto de la norma contenida en el articulo 207, letra b), del DFL $N^{\circ}$ 1-2009, del Ministerio de Transportes y Telecomunicaciones, en los autos rol $N^{\circ} 114.396-02-2011$ sobre acumulación de infracciones a la Ley de Tránsito seguidos ante el Segundo Juzgado de Policía Local de Las Condes, rol N ${ }^{\circ}$ 2045-11-INA (2012), p. 5. 
mismo se reitera en el fallo rol 2254-12-INA, de 18 de diciembre de $2012^{71}$.

Llama la atención el hecho de que el Tribunal Constitucional señale que el principio en cuestión se deduce de ciertos preceptos constitucionales, pudiendo ser, en consecuencia, un derecho implícito. Sin embargo, a renglón seguido deja constancia de que este principio se encuentra consagrado en tratados internacionales, no siendo por ello suficiente, para dar por establecido que el principio es de rango constitucional, que este se deduzca de algunos preceptos de la propia constitución. Es por ello que hemos incluido el fallo en esta segunda categoría, estimando que si el principio no estuviese recogido en tratados internacionales, la decisión de nuestra magistratura constitucional hubiese sido distinta.

i) En reiterados fallos sobre el descanso de choferes y auxiliares de buses interurbanos, comenzando con el rol 2086-11-INA, de 16 de octubre de 2012, el Tribunal llega a la conclusión de que en la práctica, debido a la forma como se distribuye la jornada, los tiempos diarios dedicados al trabajo por estos choferes y auxiliares, se prolonga en demasía, independientemente de si efectivamente están trabajando o descansando, sea a bordo o en tierra, cuestión que no les permite "disfrutar de tiempo libre para compatibilizar sus obligaciones laborales con los otros aspectos de su vida"72. Podría tratarse simplemente de una constatación de hecho, cuestión que no es propia del Tribunal Constitucional, salvo en cuanto a través de esta consideración pueda establecerse una vulneración constitucional al intentar aplicar algún precepto legal al caso particular que se esté revisando. Y es precisamente eso lo que hace el Tribunal, al constatar que por esta cuestión de hecho, se están vulnerando "los derechos del trabajador a estar sujeto a una jornada diaria de duración razonable, al descanso y a disponer libremente de su tiempo, todos los cuales están expresamente reconocidos en tratados internacionales de derechos humanos ratificados por Chile"73. Junto con el fallo citado, lo mismo se reitera

${ }^{71}$ Tribunal Constitucional, Requerimiento de inaplicabilidad por inconstitucionalidad presentado por Benjamin Jordán Astaburuaga respecto del artículo 207, letra b), del DFL $N^{\circ}$ 1-2009, del Ministerio de Transportes y Telecomunicaciones, en los autos sobre acumulación de infracciones, de que conoce el Primer Juzgado de Policía Local de Las Condes, bajo el rol No 009116-02-2012, rol N²254-12-INA (2012), p. 7.

${ }^{72}$ Tribunal Constitucional, Requerimiento de inaplicabilidad por inconstitucionalidad presentado por el Juez Titular del Segundo Juzgado de Letras del Trabajo de Santiago respecto del inciso primero, del artículo 25 del Código del Trabajo, en los autos RIT O-1630-2011, de que conoce el Segundo Juzgado de Letras del Trabajo de Santiago, rol $\mathrm{N}^{\circ}$ 2086-11-INA (2012), p. 17.

${ }^{73}$ Tribunal Constitucional, Requerimiento de inaplicabilidad por inconstitucionalidad presentado por el Juez Titular del Segundo Juzgado de Letras del Trabajo de Santiago, cit. (n. 77), p. 16. 
en los fallos roles 2110-11-INA ${ }^{74}, 2114-11-\mathrm{INA}^{75}, 2182-11-\mathrm{INA}^{76}$ y 2197 $12-\mathrm{INA}^{77}$, todos de igual fecha que el primero.

j) En los fallos roles 2096-11-INA, 2097-11-INA, 2098-11-INA y 209911-INA (acumulados), el Tribunal invoca el Convenio 102 de la Organización Internacional del Trabajo para reconocer que "las indemnizaciones por años de servicio, asi como los derechos previsionales de los trabajadores, son prestaciones que se regulan por normas de derecho público y responden a exigencias de seguridad social"78. Así, amplía la garantía establecida en el artículo 19 $\mathrm{N}^{\circ} 8$ del texto constitucional respecto de la seguridad social.

${ }^{74}$ Tribunal Constitucional, Requerimiento de inaplicabilidad por inconstitucionalidad presentado por Hernán del Tránsito Orellana Baez, Presidente del Sindicato Nacional Interempresa de Trabajadores del Transporte de Pasajeros Interurbano Rural y Cargo, respecto del inciso primero, del artículo 25 del Código del Trabajo, en los autos caratulados "Orellana con Empresa de Transportes Tur Bus Limitada", de que conoce el Segundo Juzgado de Letras del Trabajo de Santiago, bajo el RIT O-1589-2011, rol N ${ }^{\circ}$ 2110-11-INA (2012), pp. 14-16.

${ }^{75}$ Tribunal Constitucional, Requerimiento de inaplicabilidad por inconstitucionalidad de José Luis Méndez Berrios, Presidente del Sindicato de Trabajadores de Empresa Buses Ahumada. respecto del inciso primero, del artículo 25 del Código del Trabajo, en los autos caratulados "Méndez con Buses Ahumada", de que conoce el Segundo Juzgado de Letras del Trabajo de Los Andes, bajo el RIT O-24-2011, rol N 2114-11-INA (2012), pp. 11-13

${ }^{76}$ Tribunal Constitucional, Requerimiento de inaplicabilidad por inconstitucionalidad de Hernán Orellana Báez, Presidente del Sindicato Nacional Interempresa de Trabajadores del Transporte Interurbano Rural y de Carga, respecto del inciso primero del artículo 25 del Código del Trabajo en juicio laboral caratulado "Orellana con Empresa de Transportes Tur Bus Limitada”, RIT 0-3626-2011, del Segundo Juzgado del Trabajo de Santiago, rol N ${ }^{\circ}$ 2182-12-INA (2012), pp. 15-16.

${ }^{77}$ Tribunal Constitucional, Requerimiento de inaplicabilidad por inconstitucionalidad presentado por Alvaro Flores Monardes, Juez titular del Segundo Juzgado de Letras del Trabajo de Santiago, respecto del inciso primero del artículo 25 del Código del Trabajo, en los autos laborales caratulados "Riffo con Empresas de Transportes Tur Bus Limitada", de que conoce el Segundo Juzgado de Letras del Trabajo de Santiago, bajo el RIT O-3328-2011, RUC 11-4-0036456-9, rol No 2197-12-INA (2012), pp. 14-15.

${ }^{78}$ Tribunal Constitucional, Requerimiento de inaplicabilidad por inconstitucionalidad presentado por Giovanna Pamela Barrera Pino respecto de la parte que indica del inciso $3^{\circ}$ del articulo 11, de la Ley $N^{\circ} 18.834$, sobre Estatuto Administrativo, en los autos sobre recurso de nulidad laboral caratulados "Barrera con Ministerio del Interior", de que conoce la Corte de Apelaciones de Santiago, bajo el rol No 1204-2011"; "Requerimiento de inaplicabilidad por inconstitucionalidad presentado por Guillermo Crovari Belmar respecto de la parte que indica del inciso $3^{\circ}$ del articulo 11, de la Ley $N^{\circ} 18.834$, sobre Estatuto Administrativo, en los autos sobre recurso de nulidad laboral caratulados "Crovari con Ministerio del Interior", de que conoce la Corte de Apelaciones de Santiago, bajo el rol $N^{\circ}$ 1272-2011"; Requerimiento de inaplicabilidad por inconstitucionalidad presentado por Hernán César Molina Ferrari respecto de la parte que indica del inciso $3^{\circ}$ del articu- 
k) En el fallo rol 2113-12-INA, de 23 de agosto de 2012, refiriéndose a la naturaleza de las licencias maternales, sostiene el Tribunal "que, mientras las licencias médicas obedecen a patologias por morbilidad, discapacidad o incapacidad, las licencias maternales son motivadas por otra causa diferente, cual es la necesidad de potenciar la relación madre e hijo, cuyo beneficio individual, familiar y social es el que mueve al Legislador-sin tener que expresarlo en cada caso- a conferirle una 'especial protección a las madres durante un período de tiempo razonable antes y después del parto' según el Pacto internacional de derechos económicos, sociales y culturales (artículo $10 \mathrm{~N}^{\circ} 2$ )" 79 . Es interesante advertir que para justificar la diversa naturaleza de la licencia maternal respecto de las licencias médicas, el Tribunal Constitucional recurra precisamente a un tratado internacional.

\section{Casos en que el Tribunal Constitucional explica por quéno aplica algún} tratado.

a) Cabe hacer una mención al fallo rol 1971-11-INA, de 13 de diciembre de 2011. En este fallo el Tribunal Constitucional se cuida de señalar que los hechos del caso en el que recae el recurso de inaplicabilidad -arresto como medidas de apremio ante el incumplimiento de un fallo recaído en una acción por prácticas antisindicales, que ordena reintegrar a un grupo de trabajadoresno constituye una prisión por deudas. Es curioso que el Tribunal tenga tanto cuidado de señalarlo expresamente, en circunstancias que la prohibición de la prisión por deudas no se encuentra señalada en el texto constitucional, sino justamente en un tratado internacional, cual es el "Pacto de San José de Costa Rica”, que el Tribunal Constitucional cita expresamente ${ }^{80}$.

lo 11, de la Ley $N^{\circ} 18.834$, sobre Estatuto Administrativo, en los autos sobre recurso de nulidad laboral caratulados "Molina con Ministerio del Interior", de que conoce la Corte de Apelaciones de Santiago, bajo el rol No 1274-2011"; y Requerimiento de inaplicabilidad por inconstitucionalidad presentado por Leonardo Andrés Romero Fierro respecto de la parte que indica del inciso $3^{\circ}$ del artículo 11, de la Ley $N^{\circ} 18.834$, sobre Estatuto Administrativo, en los autos sobre recurso de nulidad laboral caratulados "Romero con Ministerio del Interior", de que conoce la Corte de Apelaciones de Santiago, bajo el rol $N^{\circ}$ 1345-201, roles $N^{\circ}$ 2096-11-INA, 2097-11-INA, 2098-11-INA y 2099-11-INA (acumulados) (2012), p. 12.

${ }^{79}$ Tribunal Constitucional, Requerimiento de inaplicabilidad por inconstitucionalidad de Marta Sepúlveda Vilugrón respecto del artículo $4^{\circ}$ de la ley 19.531, sustituido por el artículo $1^{\circ}$ de la ley 20.224, en los autos sobre recurso de protección, caratulados "Marta Sepúlveda Vilugrón con Corporación Administrativa del Poder Judicial", de que conoce la Corte de Apelaciones de San Miguel, bajo el rol No 149-2011, rol N²113-12-INA (2012), pp. 12-13.

${ }^{80}$ Tribunal Constitucional, Requerimiento de inaplicabilidad por inconstitucionalidad presentado por Servicio Industrial Refinería y Fundición Limitada y otro, respecto de los artículos 4 y 292 del Código del Trabajo, y 238 del Código de Procedimiento Civil, en 
b) En el fallo rol 2022-2011-INA, de 29 de marzo de 2012, por una cuestión de hecho, cual es que el requirente puede ejercer su libertad de información y de opinión sin necesariamente utilizar el espacio radioeléctrico ${ }^{81}$, el Tribunal Constitucional sostiene que no "pueden estimarse infringidos los derechos consagrados en el artículo 19 del Pacto internacional de derechos civiles y políticos y en el artículo 13.1 de la Convención americana de derechos humanos" $"$. Una vez más, nos encontramos con un caso en el que el Tribunal Constitucional se preocupa de dejar constancia de la razón por la cual deja de aplicar un tratado internacional.

c) En el fallo rol 2050-11-INA, de 25 de octubre de 2011, el Tribunal desestima la aplicación de algunas disposiciones de la Convención de derechos del niño que fueron invocadas, declarando inadmisible el recurso. Lo interesante es que lo hace porque la requirente " no señala en forma clara los bechos de la causa ni expone clara y fundadamente el modo en que se produciría la infracción de dich a norma constitucional [articulo $5^{\circ}$ en relación con la mencionada Convención] por la aplicación de los preceptos legales impugnados al caso particular" ${ }^{83}$. Es decir, el Tribunal no desestima la aplicación de la Convención por no tener rango constitucional, sino por deficiencias en la argumentación de la parte requirente.

d) En el fallo rol 2102-11-INA, de 27 de septiembre de 2012, el Tribunal discurre sobre la prisión por deudas, explicando latamente porque en el caso de deudas de carácter alimentario la privación de libertad no se considera tal. Señala el fallo que "el 'Pacto de San José de Costa Rica' permite expresamente las limitaciones a la libertad personal ordenadas judicialmente por incumplimiento de deberes alimentarios" ";

los autos rol $N^{\circ} 36-2011$ sobre recurso de amparo preventivo interpuesto ante la Corte de Apelaciones de Rancagua en contra del Juez del Primer Juzgado de letras del Trabajo de Rancagua, rol N ${ }^{\circ}$ 1971-11-INA (2011), p. 12

${ }^{81}$ Tribunal Constitucional, Requerimiento de inaplicabilidad por inconstitucionalidad deducido por Claudio Rafael Segovia Cofré respecto del artículo 36 B, letra a) de la Ley $N^{\circ} 18.168$, de Telecomunicaciones en proceso RUC 1100474360-3, Rit 913-2011 del Juzgado de Garantía de Graneros, rol No2022-2011-INA (2012), p. 19

${ }^{82}$ Tribunal Constitucional, Requerimiento de inaplicabilidad por inconstitucionalidad deducido por Claudio Rafael Segovia Cofré, cit. (n. 85), pp. 19-20

${ }^{83}$ Tribunal Constitucional, Requerimiento de inaplicabilidad por inconstitucionalidad presentado por Luz Eliana Acevedo Saravia respecto del artículo 141, inciso $1^{\circ}$, del Código Civil, en los autos RIT $N^{\circ}$ C-1335/2011, caratulados "Acevedo con Garabito", sobre declaración de bien familiar de que conoce el Segundo Juzgado de Familia de San Miguel, rol N 2050-11-INA (2011), p. 4

${ }^{84}$ Tribunal Constitucional, Requerimiento de inaplicabilidad por inconstitucionalidad presentado por Cristián Andrés Marchessi Durán respecto de los artículos 66 de la Ley $N^{\circ}$ 19.947, nueva Ley de Matrimonio Civil y 14 de la Ley $N^{\circ} 14.908$, sobre Abandono de Familia y Pago de Pensiones Alimenticias, en los autos sobre compensación económica, 
del referido pacto. El fallo hace referencia a la discusión de la ley 19.947 en el Senado ${ }^{85}$. y a la génesis del "Pacto" referido, relatando las discusiones que en las comisiones preparatorias se efectuaron sobre el tema ${ }^{86}$. para concluir que "en el 'Pacto de San José de Costa Rica' lo que se probibe es la detención por deudas, entendida ésta como privación de libertad y no como mera restricción de la misma, de manera que también desde esta perspectiva la medida de apremio de arresto nocturno satisface el baremo internacional y constitucional" ${ }^{37}$.

Es interesante apreciar el esfuerzo interpretativo realizado por el Tribunal, recurriendo incluso a herramientas propias del derecho internacional, como el recurso a la discusión habida en las comisiones preparatorias de un tratado internacional, para fundamentar la constitucionalidad de la medida de apremio, igualando el estándar internacional y constitucional.

Junto con discurrir sobre le prisión por deudas, el Tribunal reflexiona sobre la naturaleza jurídica de la compensación económica en caso de divorcio. Sostiene que a través de esta institución "se trata de igualar el punto de partida de la mujer para la vida postmatrimonial, en armonía con la Convención de naciones unidas sobre eliminación de todas las formas de discriminación contra la mujer, vigente en Chile desde el 9 de diciembre de 1989"88.

Así, para resolver el caso, el Tribunal, basándose en tratados internacionales, construye su argumentación en torno a la permisión de la prisión en caso de deudas alimentarias, y de la naturaleza alimentaria de deudas derivadas de una compensación económica. De este modo, concluye el Tribunal Constitucional que "no se infringe esa norma internacional si, para favorecer el cumplimiento de una obligación legal, como es la compensación económica establecida en favor del ex cónyuge débil, se le permite al cónyuge deudorpagarla en cuotas judicialmente determinadasy, después, ante el incumplimiento de esa facilidad, no se le sanciona penalmente sino que se le presiona o apremia para que cumpla, mediante una restricción de libertad consistente en una orden judicial de arresto nocturno"89. Queda claro que el Tribunal deja constancia de las razones por las cuales no se estarían vulnerando normas internacionales para poder negar el recurso de inaplicabilidad, y así afirmar la constitucionalidad de la institución que estaba siendo cuestionada.

caratulados "Stolzembach con Marchessi", de que conoce el Juzgado de Familia de Puerto Varas, bajo el Rit Z-70-2011, RUC 11-2-0110896-0, rol N²102-11-INA (2012), p. 28.

${ }^{85}$ Tribunal Constitucional, Requerimiento de inaplicabilidad por inconstitucionalidad presentado por Cristián Andrés Marchessi Durán, cit. (n. 85), pp. 20-21.

${ }^{86}$ Ibíd., pp. 29-30.

${ }^{87}$ Ibíd., p. 36.

${ }^{88}$ Ibíd., p. 40.

${ }^{89}$ Ibíd., p. 33. 
Entre los años 2007 y 2010 las materias en las cuales el Tribunal Constitucional recurrió a los tratados internacionales fueron, según Nogueira, las siguientes: "(A) el caso de la prisión por deudas; (B) el derecho a la identidad personal; (C) el derecho a la revisión de la sentencia penal o derecho al recurso; (D) la presunción de inocencia, y (E) la prohibición de reformatio in pejus [sic]" ${ }^{\prime 90}$. Concordamos con ello, pero nos parece necesario precisar que en los casos del derecho a la identidad y de prohibición de aumentar la pena vía recurso de casación se trata de derechos implícitos, que el Tribunal construye por vía interpretativa a partir de instrumentos internacionales que no los mencionan expresamente. En el primer caso el Tribunal extrae el derecho a la identidad del menor a partir de lo preceptuado en la Convención de derechos del niño, en el Pacto internacional de derechos civiles y politicos y en la Convención americana sobre derechos humanos; y en el segundo caso lo hace a partir de lo establecido en la última Convención citada.

En el período que analizamos en el presente trabajo, el Tribunal Constitucional vuelve a recurrir a tratados internacionales al resolver casos relativos a prisión por deudas y a presunción de inocencia, pero lo hace además en casos de diversa naturaleza. Así podemos apreciar que invoca normativa internacional para pronunciarse sobre el derecho a la vida privada y el derecho a la honra; para referirse al acceso a cargos públicos; a la igualdad ante la ley; al debido proceso, en aspectos tales como la oralidad del sistema penal, a los mecanismos para impugnar resoluciones judiciales o al principio "non bis in idem"; a cuestiones laborales y de seguridad social, tales como el derecho al descanso, derechos previsionales y licencias maternales; a la libertad de información, y por último respecto de compensaciones económicas en casos de divorcio. Así podemos observar cómo se amplía enormemente el abanico de temas en los cuales el Tribunal Constitucional considera de algún modo insuficiente el texto de la Constitución, recurriendo a los tratados internacionales para efectuar un control concreto de constitucionalidad.

\section{ConCLUSIÓN}

Nogueira sostiene que "las sentencias del Tribunal Constitucional han pasado desde una prescindencia del derecho internacional de los derechos humanos como regla general [...] a un uso moderado y tímido de las normas jurídicas internacionales"91, pero parece ser que la timidez va quedando de lado y que el Tribunal recurre cada vez más a los mencionados tratados.

La vieja discusión entre monistas y dualistas ha llevado a que el debate

${ }^{90}$ Nogueira Alcalá, Humberto, El uso del Derecho cit. (n. 4), p. 162.

${ }^{91}$ Ibíd., p. 182. 
sobre los tratados internacionales relativos a derechos humanos en nuestro medio sea sobre la jerarquía de los mismos en relación a las normas constitucionales: ¿tienen jerarquía infraconstitucional, constitucional o supraconstitucional?

Pero hay modos de avanzar en este tema, superando la discusión sobre la jerarquía. "El discurso del pluralismo constitucional renuncia a sostener $a$ priori [sic] la existencia de una relación jerárquica entre sistemas, limitando la aplicación de dicho principio a la relación entre normas específicas" ${ }^{\prime 2}$. El desafío entonces es dejar de lado la referida discusión, puesto que "las fuentes internas y las fuentes internacionales de derechos se retroalimentan" ${ }^{\text {"93. El }}$ control de convencionalidad puede ser un camino para asegurar una aplicación armónica del derecho vigente, considerando tanto sus fuentes internas, internacionales como así también las supranacionales ${ }^{94}$.

Teóricamente ha sido difícil sostener la jerarquía constitucional de los tratados sobre derechos humanos, lo que ha generado un cuarto de siglo de discusiones doctrinarias. El Tribunal Constitucional, cuando entró en esta discusión, desechó dicha postura, manteniendo que los referidos tratados tienen un rango inferior al de la Constitución. Sin embargo, a lo largo del trabajo hemos podido apreciar cómo el Tribunal utiliza estos tratados para resolver recursos de inaplicabilidad.

La única causal de inaplicabilidad de un precepto legal que contempla la Constitución, en el artículo $93 \mathrm{~N}^{\circ} 6$, es el que su aplicación resulte contraria a la Constitución, no contraria a la ley ni a un tratado internacional. Por otro lado, el Tribunal Constitucional, como su mismo nombre ya lo indica, está llamado a pronunciarse únicamente sobre cuestiones de constitucionalidad, y no cuestiones de legalidad o convencionalidad. Por ello no deja de llamar la atención que se recurra a los tratados internacionales, de jerarquía inferior a la Constitución según su propia doctrina, para resolver aspectos, precisamente, de constitucionalidad.

En ocasiones el Tribunal Constitucional sostiene que lo que se vulnera es el artículo 5 constitucional, en relación con algún tratado, pero en otras ocasiones señala que lo que se ha vulnerado es derechamente uno o más tratados. Al sostener la inaplicabilidad de un precepto legal por ser contrario a un tratado internacional, ¿no estaría el Tribunal Constitucional reconociendo jerarquía constitucional al mismo?

El Tribunal Constitucional no ha señalado expresamente que los tratados internacionales sobre derechos humanos tengan una jerarquía diferente a

\footnotetext{
${ }^{92}$ Núñez Poblete, Manuel, La función, cit. (n. 2), p. 507.

${ }^{93}$ Nogueira Alcalá, Humberto, Los derechos, cit. (n. 9).

${ }^{94}$ Nogueira Alcalá, Humberto, Diálogo cit. (n. 16), p. 78.
} 
la de otros tratados, ni menos que tengan una jerarquía igual o superior a la Constitución. Sin embargo, de hecho les reconoce jerarquía constitucional al utilizarlos para resolver cuestiones de inaplicabilidad.

Podemos, con optimismo, mirar la jurisprudencia analizada desde la óptica del pluralismo constitucional, y concluir que más que contradecir su postura anterior, en el sentido de que los tratados de derechos humanos tienen rango infraconstitucional, lo que hace el Tribunal Constitucional al resolver recursos de inaplicabilidad en base a tratados internacionales, es asumir esta óptica, o reemplazar "el discurso conflictivo de la jerarquía por el discurso dúctil de la armonización en el caso concreto" "95, como señala Núñez parafraseando a Zagrebelsky. En otras palabras, "despeja el tema de la jerarquía normativa reemplazándolo por el de la aplicabilidad preferente de la norma más protectora de los derechos o menos restrictiva de ellos" ${ }^{\prime \prime}$.

Para Nogueira, esto implica recurrir al "bloque constitucional de

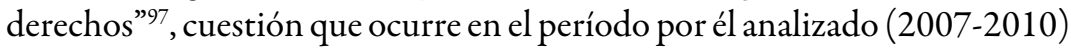
en el cual el Tribunal asume "atributos y garantías de los derechos contenidos en el derecho convencional de los derechos humanos como parte del bloque de constitucionalidad de derechos" ${ }^{\prime 8}$. Observa este autor que "la permeabilidad del orden jurídico nacional a las decisiones internacionales se ha acrecentado en el sistema interamericano como también en el sistema europeo de derechos humanos"99, cuestión que nos da pie para pensar que el pluralismo constitucional no es un mero discurso, sino una forma de abordar la solución de problemas concretos que está siendo efectivamente utilizada por los tribunales. Creemos que el Tribunal Constitucional chileno está asumiendo esta forma al resolver, al menos en algunos casos, cuestiones de inaplicabilidad.

\section{BiBLIOgRAFÍA}

BARBER, Benjamin, Why Interdependence? (Understanding Interdependence Day) [2010], disponible en http://interdependencemovement.org/documents.php.

GALDÁMEZ ZELADA, Liliana, El uso del derecho y la jurisprudencia extranjera en los fallos del Tribunal Constitucional de Chile: 2006-2010, en Revista Chilena de Derecho, 39 (2012) 1.

Henrí uez Viñas, Miriam Lorena, Jerarquía de los tratados de derechos humanos: Análisis de casos desde el método jurisprudencial, en Estudios Constitucionales, 6 (2008) 2.

\footnotetext{
${ }^{95}$ Núñez Poblete, Manuel, La función, cit. (n. 2), p. 523.

${ }^{96}$ Nogueira Alcalá, Humberto, El uso del derecho cit. (n. 4), p. 185.

${ }^{97}$ Nogueira Alcalá, Humberto, Los derechos, cit. (n. 9).

${ }^{98}$ Nogueira Alcalá, Humberto, El uso del derecho cit. (n. 4), p. 162.

${ }^{99}$ Nogueira Alcalá, Humberto, Diálogo cit. (n. 16), p. 79.
} 
Nogueira Alcalá, Humberto, Diálogo interjurisdiccional, control de convencionalidad y jurisprudencia del Tribunal Constitucional en el periodo 2006-2011, en Estudios Constitucionales, 10 (2012) 2.

Nogueira Alcalá, Humberto, El uso del derecho convencional internacional de los derechos humanos en la jurisprudencia del Tribunal Constitucional chileno en el periodo 2006-2010, en Revista Chilena de Derecho, 39 (2012) 1.

Nogueira Alcalá, Humberto, Los derechos esenciales o humanos contenidos en los tratados internacionales y su ubicación en el ordenamiento jurídico nacional: doctrina y jurisprudencia, en Ius et Praxis, 9 (2003) 1, disponible en: http://www.scielo.cl/ scielo.php?pid=S0718-00122003000100020\&script $=$ sci_arttext.

NúÑez Poblete, Manuel, Introducción al concepto de identidad constitucional y a su función frente al derecho supranacional e internacional de los derechos de la persona, en Ius et Praxis, 14 (2008) 2.

Núñez Poblete, Manuel, La función del derecho internacional de los derechos de la persona en la argumentación de la jurisprudencia constitucional. Práctica y principios metodológicos, en Revista de Derecho de la Pontificia Universidad Católica de Valparaiso, 32 (2009) 1 .

Núñez Poblete, Manuel, Sobre la declaración de inaplicabilidad de los tratados internacionales. Un estudio en defensa de su fundamento y legitimidad, en Estudios Constitucionales, 8 (2010) 2.

Ríos Álvarez, Lautaro, Jerarquía normativa de los tratados internacionales sobre derechos humanos, en Ius et Praxis, 2 (1997) 2. 
